\section{(A)POLITICAS ATUAIS}

A Revista Saúde em Redes inicia seu segundo ano de publicação, edição (janeiro, fevereiro, março) celebrando a consolidação da Editora Rede UNIDA como fomentadora de publicações de livre acesso em temas pertinentes à saúde coletiva. Com menos de três anos de fundação, publicamos o total de 58 obras (livros e periódicos). A editora visando a divulgação e promoção de seu acervo, marcou presença no 12a Congresso Internacional da Rede UNIDA, que aconteceu na cidade de Campo Grande/MS, entre os dias 21 a 24/03, com o lançamento de 22 livros, sendo destas 13 publicações da Editora Rede UNIDA, integralmente disponíveis em formatos de PDF, Flash e E-pub, na nossa biblioteca digital link: http://www.redeunida.org.br/ editora/biblioteca-digital

Aproveitamos também para divulgar que estamos no processo final de editoração da edição de suplemento da Revista Saúde em Redes que contará com todos os resumos aprovados dos trabalhos apresentados no Congresso, aguardem!!

A realização do 12 Congresso Internacional da Rede UNIDA, foi marcado por muito diálogo, onde a diversidade esteve mais uma vez presente, destacando a pluralidade das redes que congregam a Rede UNIDA, permitindo a todos e a todas um amplo debate não apenas sobre o trabalho e a educação na saúde, mas como este momento da história de nosso país clama por um olhar hibrido e atento. No qual as afetações envolvem não apenas o que é certo ou errado, mas todos os direitos conquistados com muita luta, enraizados em grande parte da população. Em contraponto a este cenário vivemos um momento de instabilidade das instituições, onde propomos refletir o quanto, estas movimentações representam uma mudança de paradigma ou se são apenas as velhas reafirmações de ações políticas conservadoras.

Lembrando Agamben, "o poder tende a uma despolitização do status de cidadão"i e que a forma de governar atual tende a agir de forma mais reativa que propriamente a analisar as causas das crises. Isso significa que os Governos mais se orientam pelas consequências, ou seja, não há um enfrentamento das causas de um determinado cenário. Invariavelmente observaremos, neste contexto, que - ambiente político se mostrará mais caótico e marcado pelo caos do que de soluções. As respostas não são discutidas, mas apresentadas na forma de discurso único, geralmente marcado por teorias e diletantismos econômicos, como se a crise fosse uma única fonte, geralmente economia.

Mas o mais perverso, como comenta Agamben, é que este discurso não deixa de servir a um propósito ou interesse de determinada camada da sociedade. Não há como não chegar à conclusão de que esta forma consequencialista ou teleológica de política está mais voltada a sobrevivência de discursos que entender e efetivamente realizar políticas públicas democráticas. A despolitização do status de cidadão ainda persiste, mesmo em um cenário em que movimentos e manifestações são vistas nas ruas e nas redes sociais. O interesse de sobrevivência da mesma forma acirra

i BOITEMPO. Agamben: A democracia é um conceito ambíguo. Entrevista especial com Giorgio Agamben. A entrevista realizada em Atenas em 17 de novembro de 2013 e publicada em italiano no Doppiozero em março de 2014. A tradução de Selvino J. Assmann. Blog da Boitempo, 04 de julho de 2014. Disponível em: <https://blogdaboitempo.com.br/2014/07/04/ agamben-a-democracia-e-um-conceito-ambiguo/\#prettyPhoto>. Acesso em: 24 mai 2016. 


\section{Editorial}

seu alcance, se apropriando do mesmo como se dele fosse lógica a sua solução. O cenário de descrédito nas instituições que vivemos, só facilita o caminho, uma vez que os argumentos são prescindíveis. Não necessita justificar as ações, já que qualquer resultado superará expectativas (in)esperadas.

Nesta edição teremos além de coletâneas de artigos originais o lançamento da seção sobre Sistemas de Saúde, com a publicação do artigo da Celia Iriart, cuja a primeira parte compõe esta edição. Convidamos a todos os autores e autoras, que desenvolvam pesquisas e análise em outros sistemas de saúde a submeter seus originais através do sistema de submissão online, disponível em nossa página.

Desejamos uma excelente leitura!

Janaina Matheus Collar

João Beccon de Almeida Neto

Editores-Executivos 